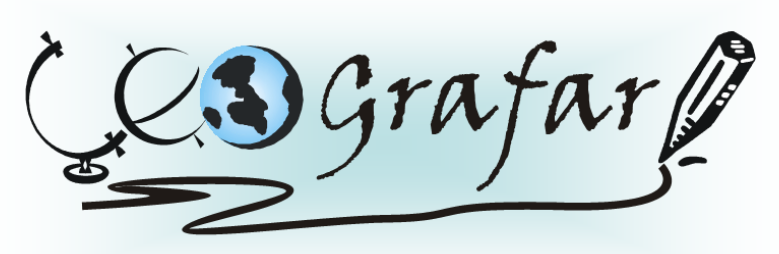

Revista Eletrônica do Programa de Pós-Graduação em Geografia - UFPR

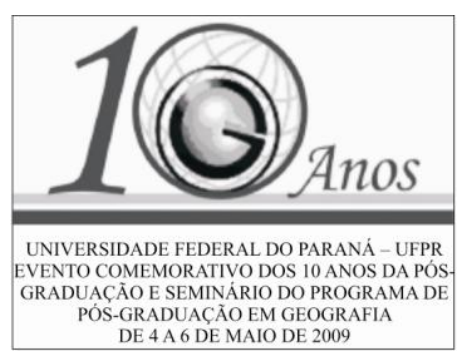

\title{
A MODELIZAÇÃO GRÁFICA, ENQUANTO MÉTODO, PARA ESTUDO E ANÁLISE DO TERRITÓRIO PARANAENSE
}

\author{
NAIR SANZOVO PIVATTO ${ }^{1}$ \\ LUIZ LOPES DINIZ FILHO ${ }^{2}$
LINHA DE PESQUISA: PRODUÇÃO E TRANSFORMAÇÃO DO ESPAÇO URBANO REGIONAL

RESUMO: As mais variadas ciências reagem de modo diferente frente aos desafios e problemas enfrentados pelos homens, bem como diante de suas solicitudes para a resolução desses problemas, nos diferentes momentos históricos. As diversas formas de abordagens do objeto geográfico variaram ao longo da história. Tal fato, muitas vezes, ocasionou uma procura por vastíssima revisão bibliográfica em variados campos afins. Desta forma, métodos e técnicas têm sido buscados de modo a dar conta da análise dos fenômenos geográficos. A presente proposta tem o intuito de, em nível de doutoramento, buscar o aprofundamento da metodologia Modelização Gráfica, um método, para estudo e análise do território paranaense.

Palavras chave: Análise do espaço paranaense. Modelização gráfica. Método.

\section{INTRODUÇÃO}

Se a geografia enquanto ciência passou por crises nos anos de 1970 e 80, hoje ela está muito mais segura de si, mais tranqüila e produz coisas interessantes, segundo Théry (2007), geógrafo francês que diz: "para nós, a geografia é uma das ciências sociais, mesmo que ela lide também com a natureza. Ela é uma das ciências sociais, mas é aquela que se preocupa com a dimensão espacial, ou seja, com as diferentes maneiras de produzir territórios”.

Para pesquisadores e geógrafos da França, a partir da década de 1990, a linha de pensamento que norteia seus trabalhos acaba com a velha divisão entre a geografia física e a geografia humana. Defendem que hoje não há mais cabimento, pois, para eles, o coração da geografia é "estudo das maneiras que a sociedade tem de produzir territórios", isto é, o território começa quando uma sociedade se apropria de um espaço e o transforma. Uma sociedade dada, num momento dado, tem poucas soluções para ocupar a transformar o seu espaço. Ela simplesmente o transforma, querendo ou não querendo, pela produção de bens, de

\footnotetext{
1 pivatto@utfpr.edu.br

${ }^{2}$ Professor orientador
} 
alimentos, construção de moradia, transporte de coisas e gente, enfim, locomovendo-se e gerenciando os seus recursos.

O território é produto e, às vezes, é subproduto da atividade humana. Para Théry, (2007) "é o nosso (do geógrafo) estudar e examinar as configurações que resultam dessas múltiplas atividades".

Devido a essas crises vivenciadas pela Geografia nos anos 1970 e 80, trabalhar com essa ciência demandava bastante preocupação aos profissionais, pois, viviam-se as manias e os modismos de inovar, de evoluir.

Assim, nossa proposta justifica-se no sentido de analisar, compreender e aplicar o método desenvolvido pelos franceses - que, aparentemente tem resistido aos modismos - e que, segundo esses geógrafos, a modelização gráfica possibilita, de modo mais seguro e tranqüilo, estudar, examinar e analisar as configurações resultantes das atividades dos homens na produção do território.

\section{2 À GUISA DE REFERENCIAL TEÓRICO}

A geografia enquanto ciência passou por diferentes maneiras de conceber a relação dos homens entre si e com a natureza ao longo do tempo, como aponta Christofoletti (1982):

- A fase Tradicional;

- A Nova Geografia;

- A Geografia Humanística;

- A Geografia Idealista;

- A Geografia Radical;

- A Geografia Têmporo-Espacial.

Ao fazer uma revisão das diferentes concepções, sobre a metodologia utilizada por cada uma delas, não pretendemos estabelecer juízo de valor, mas buscar algo novo que tome o conceito de espaço geográfico como uma noção chave, a partir da qual podemos construir os fundamentos do processo de investigação na Geografia. 


\subsection{A proposta dos franceses para a análise regional - a modelização gráfica: um método}

A modelização gráfica é proposta para ser utilizada como instrumento de análise regional, constituindo-se em um dos métodos inovadores explorados por um grupo de geógrafos franceses.

As primeiras formulações foram dadas por R. Brunet $(1980,1986,1987)$ e amplamente desenvolvidas a partir de 2001. Esse método consiste dos seguintes pressupostos:

1) A hipótese básica é que cada lugar situa-se numa série de 'campos' que estruturam o espaço - cuja interferência local forma um sistema; e que cada situação define-se em relação a afluxos, por conseguinte, em relação a centros, direções, limites.

2) Outra hipótese forte é que essas estruturas e as suas combinações podem ser representadas por modelos. Estes, por sua vez, como nas ciências "duras" são simplificados, redutores provisórios, constituindo-se uma abordagem simplificada da complexidade, um instrumento que pode ser utilizado provisoriamente, até se construir outro melhor.

3) Por último, postulam os franceses, que esses modelos podem ter uma expressão gráfica. A expressão gráfica tem sobre a discussão linear a superioridade de poder ser apreendida no espaço e, por conseguinte, de ser melhor adaptada para simplificar a organização espacial, de ser mais sintética e ter neste domínio uma melhor eficácia demonstrativa. Essa premissa supõe, contudo, que se levem em conta as regras da semiótica gráfica, que se produzam “imagens a ver e não imagens a ler”, segundo a distinção de Jacques Bertin (apud THÈRY, 2008a).

Mapas e gráficos são representações de uma determinada realidade estudada. Toda representação implica uma forma de ver e conceber a realidade, a qual é tratada cientificamente através de uma opção pessoal a partir de determinados pressupostos teóricos e metodológicos.

Segundo Martinelli (1996), "não podemos deixar de lado o inegável papel do mapa no processo de conhecimento, na busca da própria essência, como ele em si mesmo, é um momento da própria essência”. Essa essência, por conseguinte, é extraída a partir de uma visão de mundo, que foi produzida cientificamente num contexto histórico de referência.

Assim, se concebe o mundo dinamicamente, a partir de pressupostos sistêmicos, por exemplo, a representação gráfica deve buscar essa essência dinâmica da realidade em foco, utilizando-se dos parâmetros e procedimentos do referido pressuposto. 
Para Théry (2008a) "ser geógrafo é usar", isto quer dizer que devemos dizer o que nos interessa: as configurações espaciais, a formação dos territórios, e que eles (os franceses) têm desenvolvido ferramentas para chegar a esse objetivo.

Portanto, o objetivo é pesquisar, compreender, analisar e aplicar a modelização gráfica como método de análise espacial do território paranaense, de modo a contribuir com a ciência geográfica.

\section{REFERÊNCIAS}

BRUNET, R. La compositino des modèles dans l'analyse spatiale. L'Espace géographique. $\mathrm{N}^{\mathrm{o}} 4$, p.253-265, 1980.

. La carte-modèle et lês chorèmes. Mappemonde, nº 4 p. 2-6, 1986.

La carte, mode d'emploi. Paris, Fayard/Reclus, p. 269, 1987.

CARACRISTI, I. Geografia e Representações Gráficas: Uma Breve Abordagem Crítica e os Novos Desafios Técnico-Metodológicos Perpassando pela Climatologia. In: Revista Brasileira de Cartografia, $n^{\circ}$ 55/02.

CHRISTOFOLETTI, A. Perspectiva da Geografia. São Paulo:Difel, 1982.

MARTINELli, m. A Cartografia do Meio Ambiente: A Cartografia de Tudo? - Mesa Redonda: Cartografia do Meio Ambiente. $\mathbf{1 0}^{\circ}$ ENCONTRO NACIONAL DE GEÓGRAFOS, AGB, Recife, 1996.

THÈRY, H. Ciências Sociais e a identidade da Geografia. Disponível em: http://www.atmos.ggf.br||semgeo\%20 LondrinaXP.pdf. Acesso em: 14 abr.2008a.

- Modelização Gráfica para análise regional: um método. Disponível em:http//www.geografiafflch.uspbr/ publicações/Geousp/15/intercambio1pdf. Acesso em: 14 abr. 2008b.

Chaves para a leitura do território paulista. In: CONFINS. N 1/N1, 2 semestre 2007. Disponível em: http: //confins.revues.org/document25.html. Acesso em: 14 abr.2008. 